\title{
EMPOWERMENT STRATEGY MASYARAKAT DESA WISATA KEBONAGUNG KECAMATAN IMOGIRI KABUPATEN BANTUL YOGYAKARTA
}

\author{
Suharto \\ NIDN. 0530096901 \\ e-mail: hartamas1970@gmail.com \\ Dosen Akademi Pariwisata “STIPARY” YOgyakarta
}

\begin{abstract}
Research related to community empowerment strategy is taking case study in Kebonagung tourist village, Imogiri, Bantul Yogyakarta. The purpose of this research is to find the right form of empowerment strategy that aligned to the community. Qualitative research models through the instrument of observation, interviews, and documentation to collect data and facts that occurred in the community based on primary data and secondary data through data triangulation process. Interviews were conducted by researchers with determining the keyperson as resources that is the administrator of tourist village and the community. The strategies proposed in this research include cooperation strategy, cultural defection strategy, and conflict strategy through objective structural approaches as well as objective non-structural approaches.

The results showed that community involvement on the existence of tourist village from various economic and socio-cultural aspects have positive impact even though not yet fully. Openness of employment and business opportunity occurred very positively on the participation of the community in the provision of accommodation facilities, but in the social and cultural aspects has not been maximized. Empowerment strategy recommended through this research in order to reach the economic and socio-cultural aspects of the maximum is more priority to the strategy of cooperation in accordance with the culture of rural communities.
\end{abstract}

Keywords: Empowerment Strategy, Cooperation Strategy

\section{PENDAHULUAN}

Masyarakat Indonesia yang hidup dibawah garis kemiskinan umumnya tinggal di pedesaan. Sejalan dengan kondisi di atas maka tidak salah jika pemerintah mengucurkan berbagai program yang terkait dengan kemandirian masyarakat pedesaan seperti Program Nasional Pemberdayaan Masyarakat Mandiri (PNPM) di berbagai sektor usaha di pedesaan.

PNPM adalah program nasional dalam wujud kerangka sebagai dasar dan acuan pelaksanaan program - program penanggulangan kemiskinan berbasis pemberdayaan masyarakat. PNPM Mandiri Pedesaan merupakan bagian dari PNPM inti yang ditujukan bagi pemberdayaan masyarakat di pedesaan. Program ini dikembangkan dari Program Pengembangan Kecamatan (PPK) yang telah dilaksanakan sejak 1998 program ini adalah untuk meningkatkan partisipasi masyarakat dalam membangun daerahnya.

Kaitannya dengan bidang pariwisata pemerintah telah melahirkan PNPM Mandiri Pariwisata. PNPM ini adalah salah satu program penanggulangan kemiskinan yang berupaya membantu masyarakat miskin yang tinggal di sekitar wilayah destinasi pariwisata. Desadesa miskin yang menjadi sasaran PNPM-Mandiri Pariwisata adalah desa-desa yang memiliki potensi pengembangan kegiatan kepariwisataan, dekat dengan Obyek Daerah Tujuan Wisata (ODTW), maupun fasilitas pendukung pariwisata. Adapun tujuan PNPM Pariwisata yaitu pertumbuhan dan perkembangan investasi dalam industri pariwisata melalui konsep mendorong pertumbuhan daya tarik wisata unggulan di setiap provinsi (one province one primary tourism destination) bersama-sama dengan pemerintah daerah, swasta, dan masyarakat. Pengembangan paket-paket wisata yang kompetitif di masing- masing destinasi simplifikasi perizinan dan insentif perpajakan bagi investor pariwisata. Revitalisasi dan pembangunan kawasan pariwisata baru, termasuk pula prasarana dan sarana dasarnya (seperti jaringan jalan, listrik, telekomunikasi, air bersih dan sarana kesehatan). wwhttp://pnpmpedesaan.or.id/

Hingga kini sudah hampir ratusan desa wisata yang tersebar di Daerah Istimewa Yogyakarta, tetapi dari jumlah tersebut baru ada sekitar 15 (lima belas) yang secara resmi terdaftar di Dinas Pariwisata DIY. Dari jumlah tersebut salah satunya adalah Desa Wisata Kebonagung Kecamatan Imogiri Kabupaten Bantul.

Keberadaan desa wisata menjadi harapan masyarakat sebagai wahana pengentasan kemiskinan dan keterbelakangan melalui program pemberdayaan masyarakat. Desa wisata diharapkan mampu mengkomunikasikan berbagai bentuk kebutuhan untuk mewujudkan kesejahteraan masyarakat. Desa wisata bagian dari komunitas masyarakat.

Agar keberadaan desa wisata bisa memberikan kontribusi nyata dalam peningkatan kesejahteraan masyarakat maka diperlukan strategi bagaimana memberdayakan masyarakat di wilayah obyek wisata tersebut. Penerapan strategi adalah langkah awal untuk menuju ketepatan sasaran. Fenomena menunjukkan bahwa ada beberapa lembaga sosial maupun ekonomi di masyarakat desa yang kurang tepat sasaran. 
Desa wisata adalah salah satu bentuk kelompok ekonomi dan sosial yang berada ditengah masyarakat yang diharapkan memberikan kontribusi secara ekonomi, sosial dan budaya melalui strategi pemberdayaan masyarakat itu sendiri.

Bentuk strategi pemberdayaan masyarakat melalui desa wisata diantaranya dapat dilakukan melalui berbagai cara diantaranya memberikan kesempatan untuk berpartisipasi aktif dalam membuka kesempatan kerja, membuka kesempatan peluang berusaha, memberikan kesempatan masyarakat untuk mengembangkan desa wisata dan secara sosial dapat dipakai pula sebagai wahana pembentukan karakter sosial dan budaya bagi masyarakatnya.

Fokus kajian penelitian ini mengekplorasi upaya desa wisata Kebonagung menciptakan strategi pemberdayaan masyarakat yang secara lansung bermanfaat bagi pengembangan masyarakat desa wisata Kabonagung di masa mendatang.

\section{LITERATURE REVIEW}

\section{Pengertian, Terminologi dan Tujuan Pemberdayaan Masyarakat}

Secara umum pengertian pemberdayaan mengarah kepada berbagai upaya untuk memperkuat posisi seseorang melalui penumbuhan kesadaran dan kemampuan individu dalam mengidentifikasi persoalan yang dihadapi, mengambil keputusan dan menentukan tindakan yang akan dilakukan. Memberdayakan masyarakat bertujuan mendidik masyarakat agar mampu mendidik diri mereka sendiri atau membantu masyarakat agar mampu membantu diri mereka sendiri.

Pemberdayaan masyarakat bisa dilakukan oleh banyak elemen: pemerintah, perguruan tinggi, lembaga swadaya masyarakat, pers, partai politik, lembaga donor, aktor - aktor masyarakat sipil, atau oleh organisasi masyarakat lokal sendiri. Birokrasi pemerintah tentu saja sangat strategis karena mempunyai banyak keunggulan dan kekuatan yang luar biasa ketimbang unsur-unsur lainnya: mempunyai dana, aparat yang banyak, kewenangan untuk membuat kerangka legal, kebijakan untuk pemberian layanan publik, dan lain-lain.

Proses pemberdayaan bisa berlangsung lebih kuat, komprehensif dan berkelanjutan bila berbagai unsur tersebut membangun kemitraan dan jaringan yang didasarkan pada prinsip saling percaya dan menghormati (Sutoro Eko, 2002).

Salah satu tahapan dalam pemberdayaan adalah meningkatkan peran serta masyarakat. Secara sederhana peran serta masyarakat dapat diartikan sebagai upaya terencana untuk melibatkan masyarakat dalam proses pembuatan kebijakan dan pengambilan keputusan. Peran serta juga dapat diartikan sebagai suatu proses dimana pihak yang akan memperoleh dampak (positif dan/atau negatif) ikut mempengaruhi arah dan pelaksanaan kegiatan, tidak hanya menerima hasilnya.

Secara umum bentuk peran serta masyarakat dapat dibedakan menjadi empat tahapan, yaitu partisipasi dalam :

1. Tahap pembuatan keputusan; dalam hal ini, sejak awal masyarakat telah dilibatkan dalam proses perencanaan dan perancangan kegiatan serta dalam pengambilan keputusan atas rencana yang akan dilaksanakan.

2. Tahap implementasi; keterlibatan masyarakat juga diupayakan pada tahap pelaksanaan kegiatan. Dengan demikian, masyarakat dapat mengontrol bagaimana kegiatan dilaksanakan di lapangan.

3. Tahap evaluasi; tahap ini dilakukan secara periodik umumnya dilaksanakan pada tahap pelaksanaan dan pada akhir pelaksanaan kegiatan.

4. Tahap partisipasi untuk memperoleh manfaat suatu kegiatan.

Tujuan umum yang akan dicapai melalui usaha pemberdayaan masyarakat, adalah terwujudnya masyarakat yang mandiri, berswadaya, mampu mengadopsi inovasi, dan dapat berperan serta dalam berbagai aktivitas pembangunan. Dengan kata lain, pemberdayaan masyarakat bertujuan untuk meningkatkan potensi masyarakat agar mampu meningkatkan kualitas hidup yang lebih baik bagi seluruh warga masyarakat melalui kegiatan-kegiatan swadaya. Sedangkan tujuan khusus mencakup hal-hal sebagai berikut:

1. Memastikan bahwa program pemberdayaan masyarakat yang telah diprakarsai, dirancang, difasilitasi, dan dilaksanakan oleh program tetap berlangsung setelah program berakhir.

2. Memastikan bahwa lembaga-lembaga kemasyarakatan yang telah terbentuk selama program tetap hidup, mampu mandiri, dan berperan secara tepat setelah program berakhir.

3. Memastikan bahwa pemerintah dengan instansiinstansinya tetap memfasilitasi lembaga kemasyarakatan setelah pekerjaan berakhir.

4. Memastikan bahwa terjadi perbaikan taraf hidup masyarakat secara berkesinambungan setelah program berakhir.

Manfaat pemberdayaan masyarakat dapat dirasakan tidak hanya oleh masyarakat itu sendiri, tapi juga oleh pemerintah, masyarakat non pemerintah/ swasta dan lingkungannya. Beberapa manfaat yang dapat dipetik dari upaya pemberdayaan, antara lain :

1. Bagi masyarakat, pemberdayaan masyarakat dengan keberadaan desa wisata akan membangun kesadaran masyarakat dan pihak lain atas hak masyarakat untuk ikut serta dalam pengambilan keputusan, menyusun rencana kegiatan, melaksanakan kegiatan, memantau dan melakukan mengevaluasi kegiatan dalam berbagai kegiatan yang berkaitan dengan pengembangan wilayah khususnya bidang pariwisata. Dengan demikian, masyarakat menjadi subyek pelaku sekaligus penerima manfaat utama dari kegiatan. 
2. Bagi pemerintah, pemberdayaan masyarakat akan membuka kemungkinan keputusan yang dibuat sesuai dengan kebutuhan dan prioritas masyarakat, menjamin penerimaan dan apresiasi dari masyarakat, mewujudkan visi pemerintah sebagai fasilitator dalam pengembagan bidang pariwisata.

3. Bagi lingkungan, pemberdayaan masyarakat akan bermanfaat karena masyarakat adalah pelaku utama dan penerima manfaat akibat dan manfaat dari pengelolaan lingkungan, baik yang merusak ataupun yang melestarikan. Pembangunan yang berkelanjutan memerlukan masyarakat yang berdaya, yang dapat mengelola lingkungannya secara arif dan lestari.

Strategi Pemberdayaan dan Manfaatnya Bagi Masyarakat

Terdapat 3 (tiga) pilar utama yang menjadi strategi dalam melaksanakan pemberdayaan masyarakat yaitu:

1. Penciptaan suasana atau iklim yang memungkinkan berkembangnya potensi dan daya yang dimiliki oleh masyarakat.

2. Memperkuat potensi atau daya yang dimiliki oleh masyarakat.

3. Melindungi masyarakat melalui keberpihakan kepada masyarakat untuk mencegah dampak persaingan yang tidak adil

Ketiga strategi pemberdayaan masyarakat tersebut bermuara pada tiga langkah konkret, yaitu:

1. Secara konkret pemberdayaan masyarakat diupayakan melalui pembangunan ekonomi rakyat.

2. Pemberdayaan masyarakat diarahkan pada terwujudnya transfomasi struktur sosial secara bertahap.

3. Pengembangan kelembagaan, melalui pemberdayaan masyarakat, harus diupayakan adanya pengembangan kelembagaan (institutional development).

Dalam konteks ini perlu dilakukan peningkatan fungsi (revitalisasi) organisasi masyarakat bahkan perlu diupayakan pembaharuan (reformasi) dan perubahan (transformasi) organisasi masyarakat tersebut, sehingga keberadaannya benar-benar dapat menjadi peluang yang terbuka bagi seluruh anggota masyarakat untuk ikut serta dalam proses pembangunan.

Senada dengan program pembangunan pedesaan, J. Nasikun (dalam Jefta Leibo,1995), mengajukan strategi yang meliputi : (1) Startegi pembangunan gotong royong, (2) Strategi pembangunan Teknikal Profesional, (3) Strategi Konflik, (4) Strategi pembelotan kultural.

Dalam strategi gotong royong, melihat masyarakat sebagai sistem sosial. Artinya masyarakat terdiri dari bagian-bagian yang saling kerjasama untuk mewujudkan tujuan bersama. Gotong royong dipercaya bahwa perubahan-perubahan masyarakat, dapat diwujudkan melalui partisipasi luas dari segenap komponen dalam masyarakat. Prosedur dalam gotong royong bersifat demokratis, dilakukan diatas kekuatan sendiri dan kesukarelaan.

1. Strategi pembangunan Teknikal - Profesional, dalam memecahkan berbagai masalah kelompok masyarakat dengan cara mengembangkan norma, peranan, prosedur baru untuk menghadapi situasi baru yang selalu berubah. Dalam strategi ini, peranan agen - agen pembaharuan sangat penting. Peran yang dilakukan agen pembaharuan terutama dalam menentukan program pembangunan, menyediakan pelayanan yang diperlukan, dan menentukan tindakan yang diperlukan dalam merealisasikan program pembangunan tersebut. Agen pembaharuan merupakan kelompok kerja yang terdiri atas beberapa warga masyarakat yang terpilih dan dipercaya untuk menemukan cara - cara yang lebih kreatif sehingga hambatan - hambatan dalam pelaksanaan program pembangunan dapat diminimalisir.

2. Strategi Konflik, melihat dalam kehidupan masyarakat dikuasasi oleh segelintir orang atau sejumlah kecil kelompok kepentingan tertentu. Oleh karena itu, strategi ini menganjurkan perlunya mengorganisir lapisan penduduk miskin untuk menyalurkan permintaan mereka atas sumber daya dan atas perlakuan yang lebih adil dan lebih demokratis. Strategi konflik menaruh tekanan perhatian pada perubahan organisasi dan peraturan (struktur) melalui distribusi kekuasaan, sumber daya dan keputusan masyarakat.

3. Strategi pembelotan kultural, menekankan pada perubahan tingkat subyektif individual, mulai dari perubahan nilai-nilai pribadi menuju gaya hidup baru yang manusiawi. Yaitu gaya hidup cinta kasih terhadap sesama dan partisipasi penuh komunitas orang lain. Dalam bahasa Pancasila adalah humanisrelegius. Strategi ini merupakan reaksi (pembelotan) terhadap kehidupan masyarakat modern industrial yang berkembang berlawanan dengan pengembangan potensi kemanusiaan.

Manfaat pemberdayaan masyarakat dapat dirasakan tidak hanya oleh masyarakat itu sendiri, tetapi juga oleh pemerintah, masyarakat, non pemerintah/swasta dan lingkungannya. Beberapa manfaat yang dapat dipetik dari upaya pemberdayaan, antara lain :

1. Bagi masyarakat, pemberdayaan masyarakat dalam pengelolaan sumber daya air akan membangun kesadaran masyarakat dan pihak lain atas hak masyarakat untuk ikut serta dalam pengambilan keputusan, menyusun rencana kegiatan, melaksanakan kegiatan, memantau dan mengevaluasi kegiatan dalam pengelolaan sumber daya air. Dengan demikian, masyarakat menjadi subyek pelaku sekaligus penerima manfaat utama dari kegiatan.

2. Bagi pemerintah, pemberdayaan masyarakat akan membuka kemungkinan keputusan yang dibuat sesuai dengan kebutuhan dan prioritas masyarakat, menjamin penerimaan dan apresiasi dari masyarakat, mewujudkan visi pemerintah sebagai fasilitator dalam pengelolaan sumber daya air. 
3. Bagi lingkungan, pemberdayaan masyarakat akan bermanfaat karena masyarakat adalah pelaku utama dan penerima manfaat akibat dan manfaat dari pengelolaan lingkungan, baik yang merusak ataupun yang melestarikan. Pembangunan yang berkelanjutan memerlukan masyarakat yang berdaya, yang dapat mengelola lingkungannya secara arif dan lestari.

\section{Desa Wisata}

Secara umum di berbagai literature pengertian desa wisata yaitu sebuah istilah yang diadopsi dari beberapa pengertian tentang jenis pariwisata yaitu ;

1. Agrowisata (wisata pertanian) yaitu jenis wisata yang memfokuskan pada pertanian atau perkebunan yang khas sebagai objek kunjungan. Jenis wisata yang seperti ini biasanya telah dikembangkan sedemikian rupa sehingga berbagai aspek yang terkait dengan jenis tumbuhan yang dibudidayakan itu menimbulkan motivasi dan daya tarik bagi wisatawan untuk mengunjunginya. (RS Damardjati:5)

2. Wisata budaya yaitu gerak atau kegiatan wisata yang dirangsang oleh adanya obyek -obyek wisata berujud hasil-hasil seni budaya setempat, misalnya adat-istiadat; upacara-upacara agama, tata hidup masyarakat, peninggalan-peninggalan sejarah, hasil-hasil seni dan kerajinan rakyat, dan lain sebagainya. (RS Damardjati :31)

3. Ekoturisme yaitu merupakan usaha dan kegiatan kepariwisataan dengan penyelenggaraan perjalanan ke daerah-daerah lingkungan alam disertai kesadaran penuh tentang adanya tanggung jawab yang tinggi terhadap pelestarian lingkungan alam dan peningkatan kesejahteraan penduduk setempat. (RS Damardjati :39)

Desa Wisata yaitu sebuah kawasan yang berkaitan dengan wilayah atau berbagai kearifan lokal (adat, budaya, potensi, yang dikelola sebagai obyek wisata sesuai dengan kemampuannya, yang ditujukan untuk kepentingan sosial dan ekonomi pada masyarakat. Kearifan lokal atau kearifan tradisional atau sistem pengetahun lokal yang dimaksud disini adalah pengetahun yang khas yang milik suatu masyarakat atau budaya tertentu yang telah berkembang sekian lama, sebagai hasil dari proses hubungan timbal balik antara penduduk tersebut dengan lingkungannya (Petunjuk Teknis Penelitian Budaya, anonym, Yogyakarta : P2KD Diy 2003.)

\section{Kerangka Pemikiran}

Untuk menuntun penelitian dalam pencapaian tujuan penelitian, maka perlu disusun skema kerangka pikir penelitian. Berkaitan dengan hal tersebut maka dari uraian di atas mengenai teorisasi penelitian dapat diformulasikan kerangka pemikiran sebagai berikut :

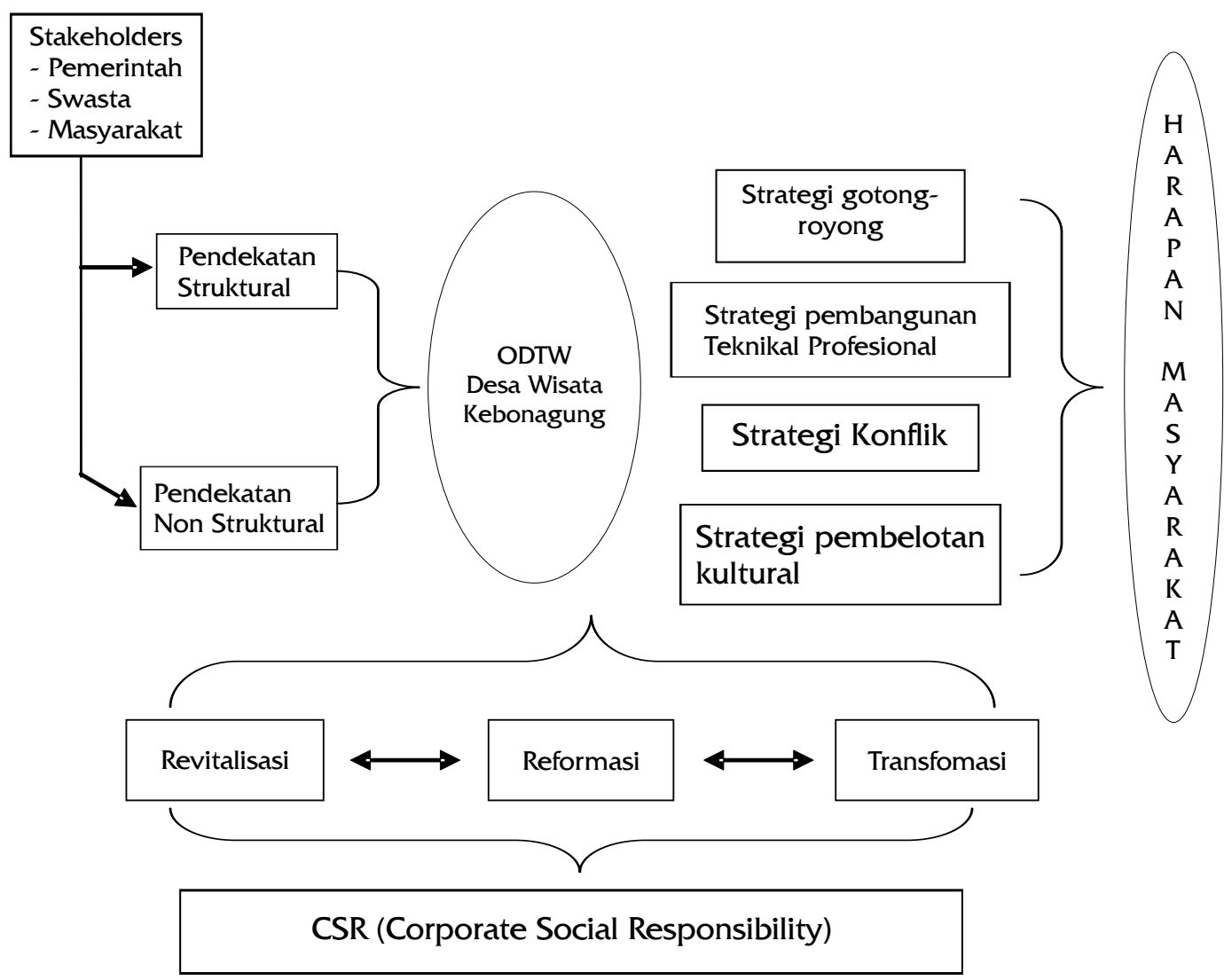




\section{METODE PENELITIAN}

Data penelitian ini terdiri dari data primer dan data sekunder yang dikumpulkan dengan metode observasi, wawancara dan dokumentasi dari sejumlah data berikut

\begin{tabular}{|l|l|l|l|}
\hline Bidang Pemberdayaan & \multicolumn{1}{|c|}{ Pendekatan } & \multicolumn{1}{|c|}{ Strategi } & \multicolumn{1}{c|}{ Indikator } \\
\hline \multirow{2}{*}{ Ekonomi } & $\begin{array}{l}\text { Stuktural } \\
\text { Obyektif }\end{array}$ & $\begin{array}{l}\text { Strategi gotong royong, } \\
\text { Strategi pembelotan kultural } \\
\text { Strategi Konflik }\end{array}$ & $\begin{array}{l}\text { Pendapatan masyarakat } \\
\text { Peluang usaha, peluang } \\
\text { kerjasama usaha }\end{array}$ \\
\cline { 2 - 5 } & $\begin{array}{l}\text { Non struktural } \\
\text { Subyektif }\end{array}$ & $\begin{array}{l}\text { Strategi pembangunan } \\
\text { Teknikal - Profesional } \\
\text { Strategi pembelotan kultural }\end{array}$ & $\begin{array}{l}\text { Kesempatan kerja, } \\
\text { pengembangan ketrampilan } \\
\text { masyarakat, bantuan dana, } \\
\text { media informasi }\end{array}$ \\
\hline \hline \multirow{2}{*}{ Ekonomi } & $\begin{array}{l}\text { Stuktural } \\
\text { Obyektif }\end{array}$ & $\begin{array}{l}\text { Strategi pembelotan kultural } \\
\text { Strategi Konflik }\end{array}$ & $\begin{array}{l}\text { Pengembangan kualitas diri, } \\
\text { pengambilan keputusan }\end{array}$ \\
\cline { 2 - 5 } & $\begin{array}{l}\text { Non struktural } \\
\text { Subyektif }\end{array}$ & $\begin{array}{l}\text { Strategi Konflik } \\
\text { Strategi pembelotan kultural }\end{array}$ & $\begin{array}{l}\text { Peningkatan wawasan dan } \\
\text { pengetahuan lingkungan, } \\
\text { kapasitas kelembagaan, }\end{array}$ \\
\hline \hline \multirow{2}{*}{ Budaya } & $\begin{array}{l}\text { Stuktural } \\
\text { Obyektif }\end{array}$ & $\begin{array}{l}\text { Strategi pembelotan kultural } \\
\text { Strategi pembelotan kultural } \\
\text { Strategi gotong royong }\end{array}$ & $\begin{array}{l}\text { peran dan partisipasi } \\
\text { masyarakat, pengambilan } \\
\text { keputusan }\end{array}$ \\
\cline { 2 - 5 } & $\begin{array}{l}\text { Subyektif } \\
\text { pembangunan Teknikal - } \\
\text { Profesional } \\
\text { Strategi pembelotan kultural }\end{array}$ & $\begin{array}{l}\text { Penggalian dan } \\
\text { pengembangan nilai-nilai } \\
\text { lokal, Pengawasan berbasis } \\
\text { masyarakat }\end{array}$ \\
\hline
\end{tabular}

\section{HASIL PENELITIAN DAN PEMBAHASAN}

\section{Bentuk Pemberdayaan Pada Potensi Wisata}

Konsep 3A (Aksesibilitas, Amenitas, Atraksi) Desa Wisata Kebonagung, cukup unik dan vareatif segala sesuatu yang memiliki keunikan dan keindahan nilai yang berupa keanekaragamam kekayaan budaya dan hasil buatan manusia yang menjadi sasaran atau tujuan kunjungan wisatawan. Basis utama dari kekhususan daya tarik wisata adalah berbasis pada pertanian, sumber air/sungai (bendung) dan kerajinan lokal serta lokasi wilayah yang nyaman, aman, jauh dari polusi udara kotor.

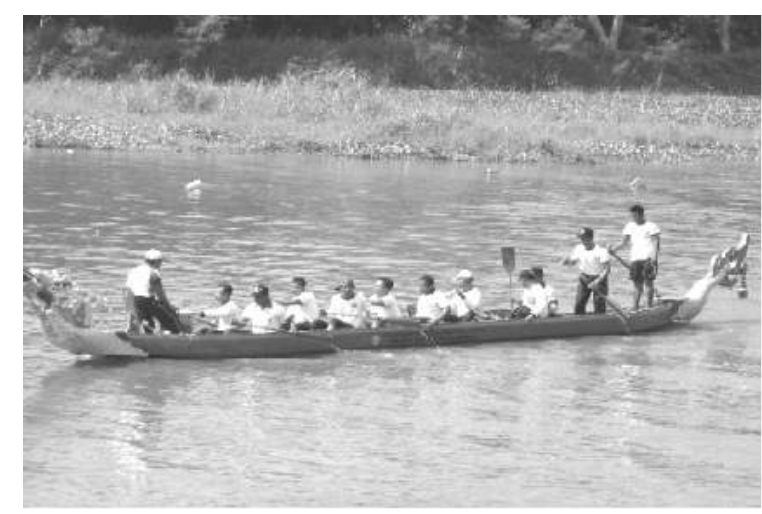

Bermula dari keberadaan sebuah bendungan kali Opak tinggalan jaman Belanda yang berada di Dusun Tegal dan kirab budaya di Desa Kebonagung sebagai embrio keberadaan desa wisata. Keberadaan Bendungan yang selanjutnya dikenal dengan nama Bendung Tegal yang semula hanya untuk pengairan sektor pertanian dikelola oleh masyarakat sebagai arena olah raga bagi wisatawan yaitu Perahu Dayung dan Flying Fox disamping tetap mempertahankan atraksi kirab budaya yang berbasis hasil pertanian. Berikut dokumentasi kedua potensi wisata diatas

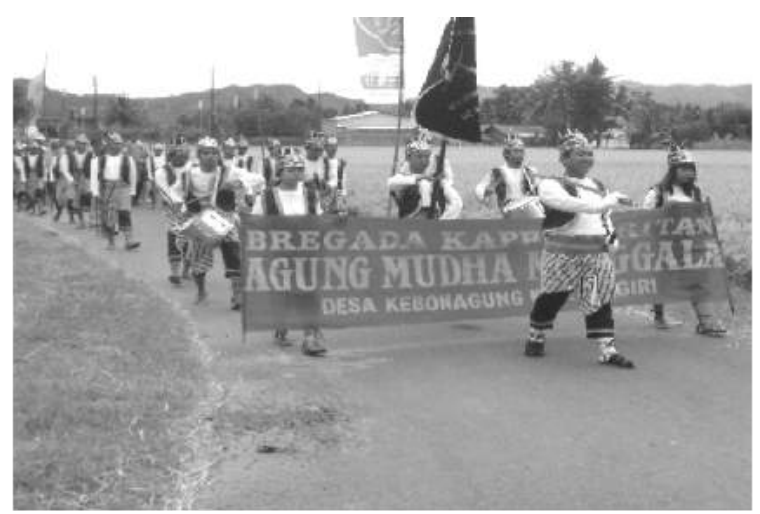




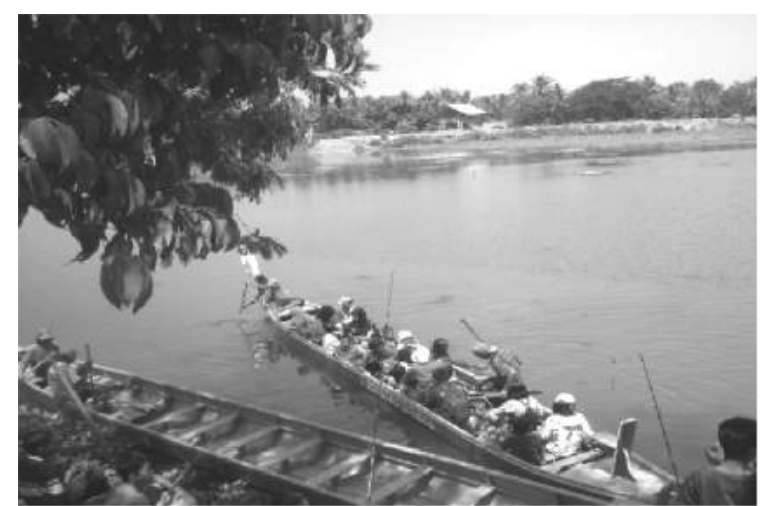

Keberadaan air yang melimpah mendukung sektor pertanian berkembang sangat baik, keberadaan ini tidak disia-siakan oleh para pengelola desa wisata bekerjasama dengan masyarakat petani dan peternak untuk menjadikan sawah dan hewan ternak mereka

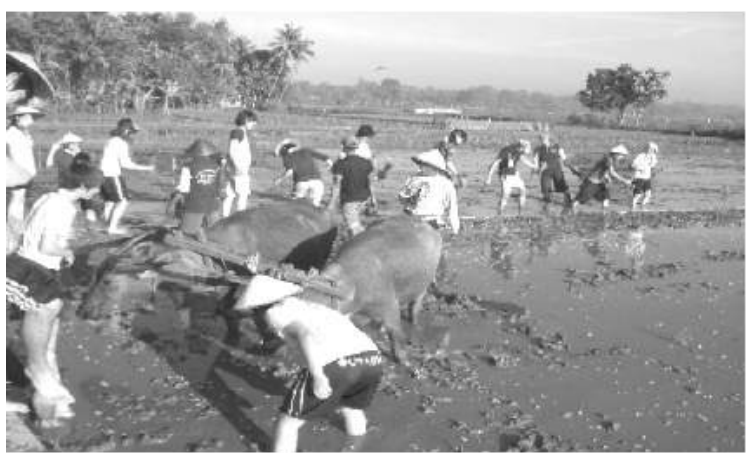

Keberadaan lahan bentuk tanah kas Desa Kebonagung sangat memberikan kontribusi yang berarti pada atraksi wisata remaja berbentuk outbond, khususnya pada wisatawan muda/pelajar dari luar kota Yogyakarta.

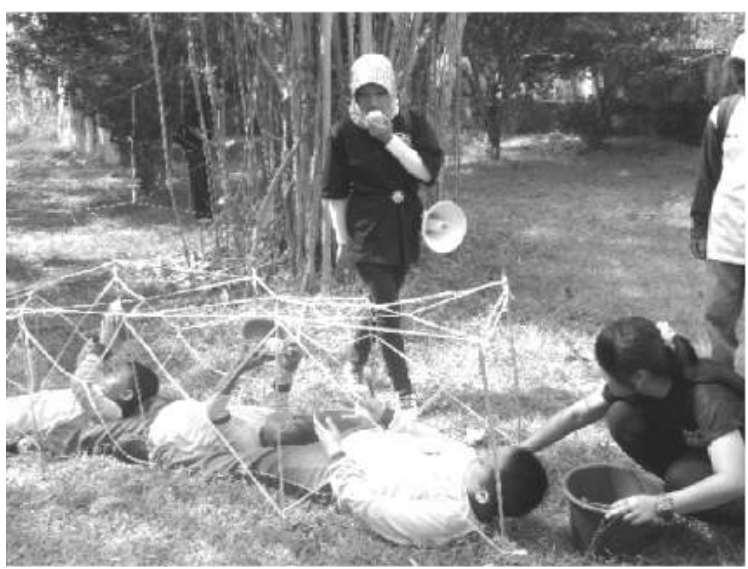

Hamparan tanah kas desa yang berada di tepian sungai opak yang cukup luas memberikan keleluasaan arena outbond dan arena sepeda kampung sebagai wahana melepas kejenuhan bagi wisatawan tidak saja untuk anak-anak sekolah tetapi juga wisatawan usia remaja, orang tua, maupun wisatawan usia senja. Atraksi sepeda

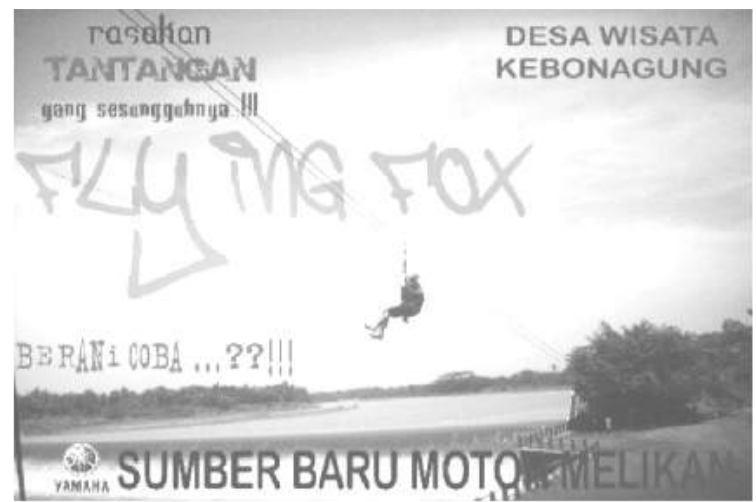

sebagai daya tarik baru bagi wisatawan asing untuk belajar bercocok tanam padi dan mengolah tanah pertanian secara tradisional melalui hewan ternak kerbau.

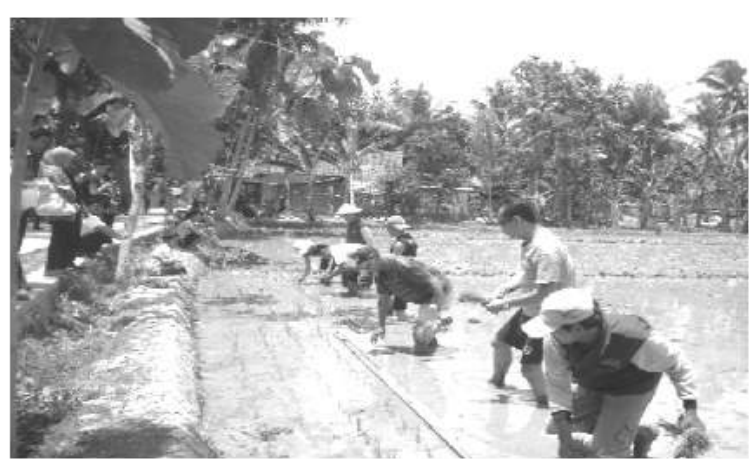

Berikut salah satu dokumentasi yang peneliti temukan mengenai kegiatan outbond yang dilaksanakan oleh salah satu rombongan wisata pelajar dari SMP JUBILEE Jakarta pada bulan Oktober 2016.

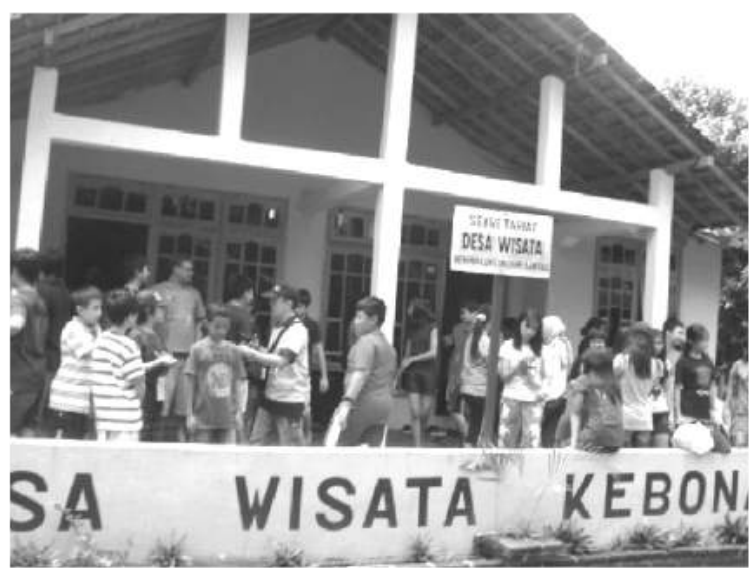

kampung bantuan dari Bank BPD DIY memberikan hiburan tersendiri bagi wisatawan luar kota untuk menikmati keindahan bendung opak dan aktifitas para petani ditengah-tengah segarnya udara yang jauh dari polusi 


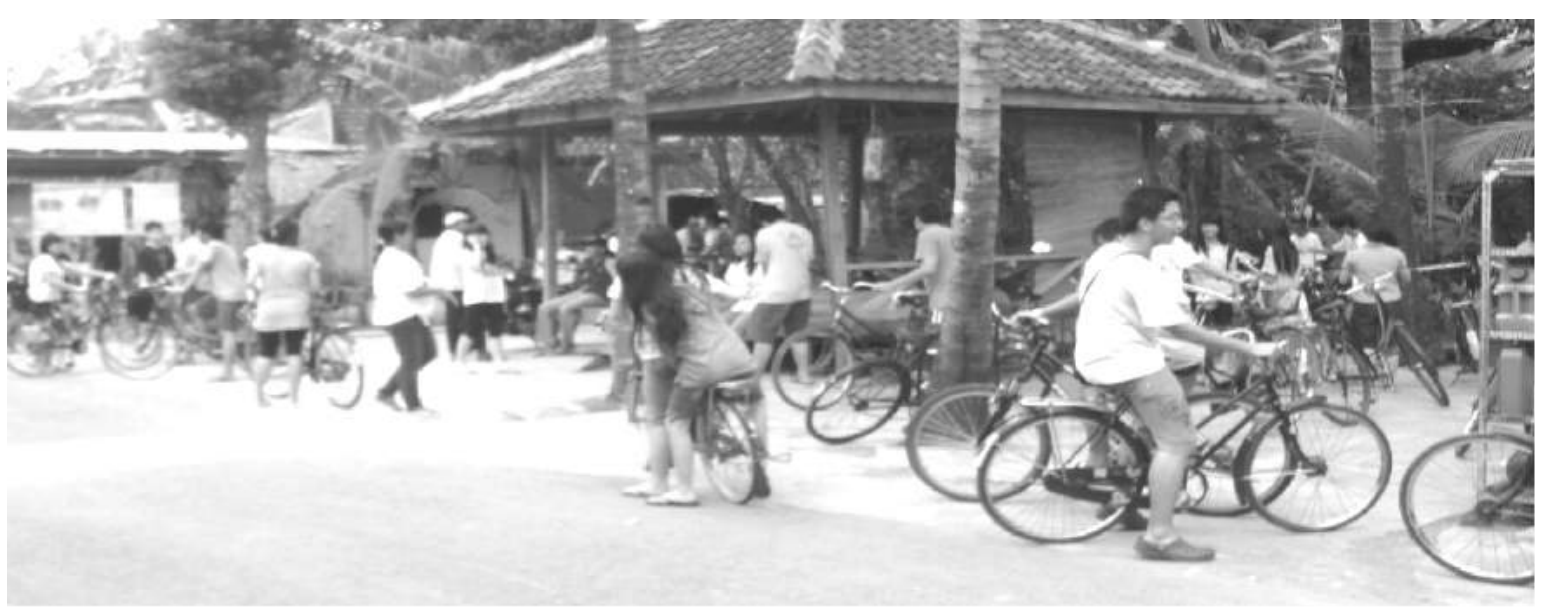

Bentuk pemberdayaan lain bagi masyarakat desa kebonagung adalah berbagai keaktifan warga dalam bentuk rembug desa tentang berbagai perencanaan pengembangan desa wisata. Tidak ketinggalan pula

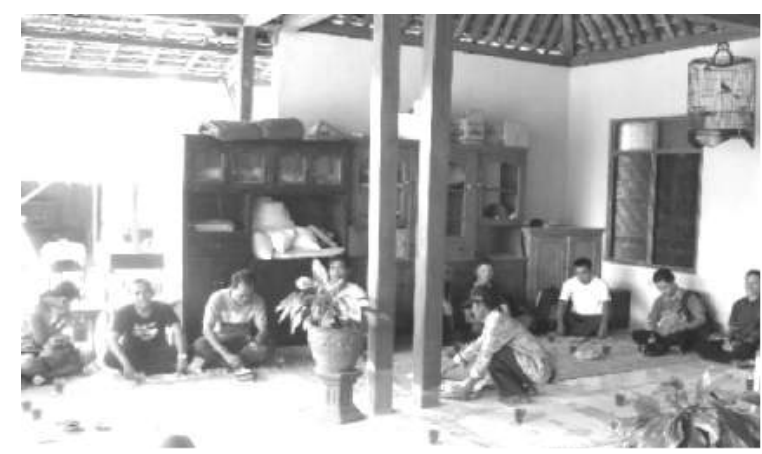

Sumbangan ekonomi yang langsung berdampak pada keuangan warga masyarakat adalah keberadaan homestay sebagai sarana akomodasi bagi wisatawan disamping telah memberikan kontribusi pemberdayaan sosial, ekonomi/keuangan keluarga juga berdampak

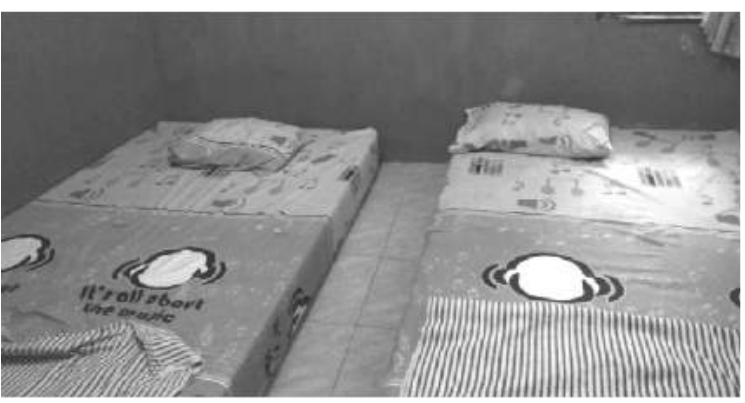

aktivitas para ibu-ibu dalam melayani para wisatawan. Berikut beberapa dokumentasi yang peneliti temukan ketika eksplorasi lapangan mengenai berbagai keaktifan warga masyarakat.

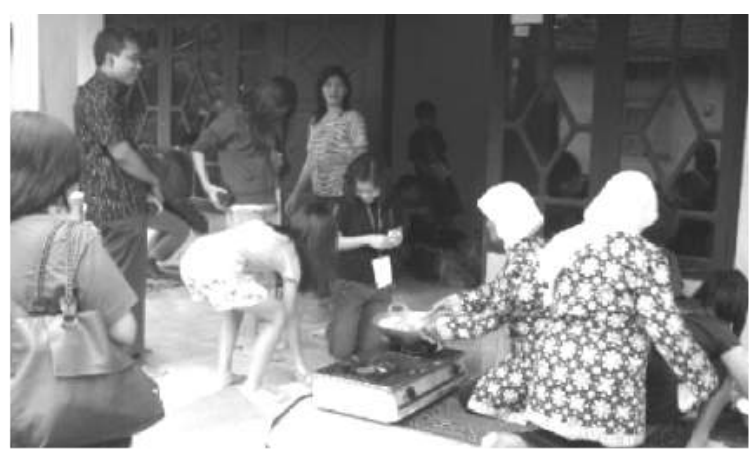

pada kepekaan warga terhadap kebersihan lingkungan (sanitasi) bagi rumah tangga. Homestay yang tersedia cukup representatif untuk kebutuhan akomodasi secara pribadi maupun kelompok.
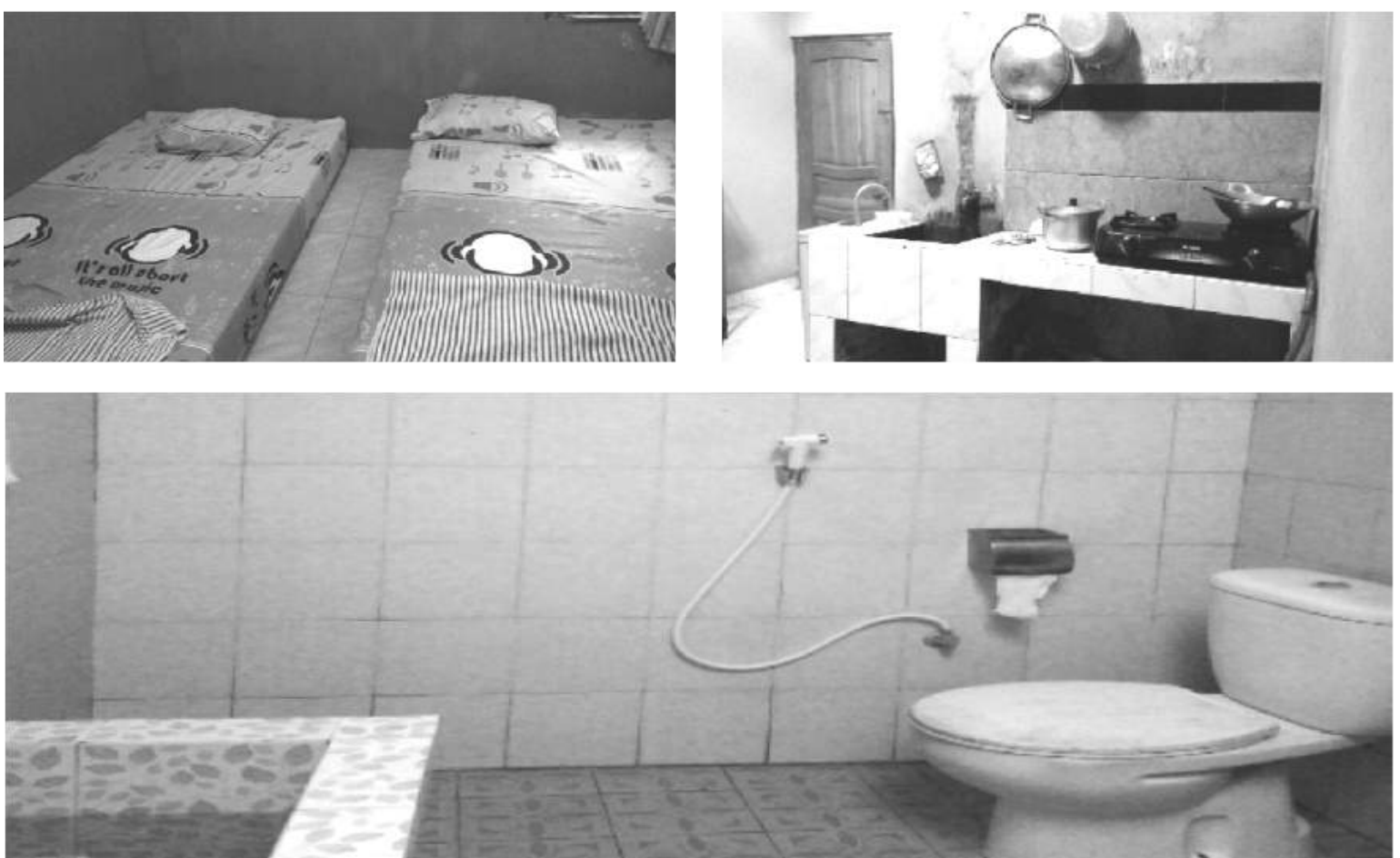
Perkembangan kebutuhan wisatawan terhadap homestay yang disediakan oleh masyarakat. Berdasarkan penjelasan yang peneliti terima dari Bapak
Sardi dan Bapak Sugiyanto selaku seksi homestay diperoleh keterangan yang peneliti lukiskan dalam kedua bentuk grafik garis berikut ini :

\section{PERKEMBANGAN JUMLAH HOMESTAY}

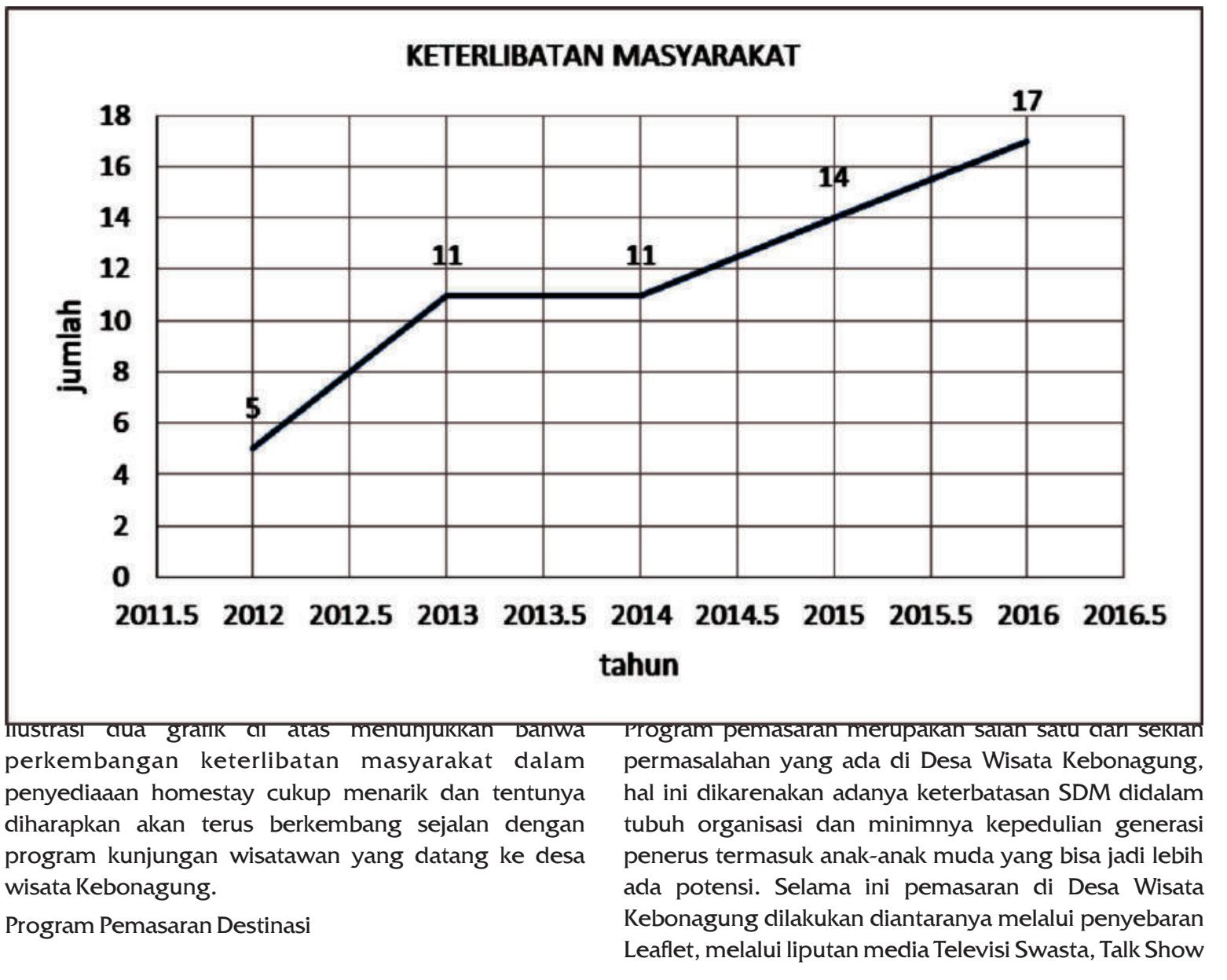


dan tentunya Program Pemasaran banyak dibantu oleh Dinas Pariwisata dan kalangan Mahasiswa di Perguruan Tinggi yang ada di DIY.

Keterlibatan masyarakat dalam program pemasaran secara rutin hanya sebanyak 7 orang yang diketuai oleh Bapak Sardi yang sekaligus sebagai seksi homestay. Keterlibatan penduduk yang sangat terbatas ini dikarenakan belum ada keberanian untuk berkomunikasi dalam bahasa Inggris, maupun kurangnya penguasaan tentang keberadaan desa wisata itu sendiri. Berikut petikan wawancara dengan Pak Sardi

"saya dulu bekerja sebagai tukang becak yang biasa nongkrong di sekitaran Prawirotaman saya sering komunikasi dengan para wisatawan asing dan saya masih banyak punya teman yang seprofesi dengan saya maupun teman-teman yang bekerja sebagai pemandu wisata. Pengalaman masa lalu saya itulah yang saya manfaatkan sebagai modal untuk memasarkan desa Wisata Kebonagung. Setiap dua hari sekali saya sering nongkrong di Prawirotaman maupun di beberapa hotel di jalan Taman Siswa Yogyakarta untuk mencari tamu dan berkomunikasi dengan teman-teman untuk memasarkan Desa Wisata Kebonagung. Kebanyakan dari teman-teman lama saya, saya berikan fee jika membawa tamu dan untuk masyarakat dusun Jayan dan Tegal sudah saya berikan pelatihan dan ikut saya jika bernegosiasi dengan tamu sehingga mereka punya pengalaman untuk memasarkan, namun demikian ada beberapa tenaga yang tidak krasan/betah khususnya anak anak muda kurang berani menghadapi tantangan".

Selanjutnya Pak Sardi mengatakan :

"Dalam memasarkan secara langsung pengalaman saya bahwa tenaga pemasaran harus luwes/fleksibel berhubungan dengan pengusaha transportasi mengingat jarak antara Prawirotaman dengan Desa Kebonagung cukup jauh, disamping itu juga pemberian komisi kepada teman-teman yang seprofesi dengan saya jangan sampai mengecewakan

Tabel 1. Jenis Pekerjaan di DesaWisata Kebonagung sehingga dapat merupakan pemicu untuk membantu memasarkan".

Pada saat peneliti mengkonfirmasikan kepada pengelola Desa wisata berkaitan dengan rendahnya tenaga pemasaran dan upaya apa yang dilakukan sebagai bentuk pemberdayaan masyarakat untuk program pemasaran yang ada didapatkan keterangan dari Bapak. Bachroni selaku Ketua menjelaskan:

"ini memang tantangan terberat ketika para pemuda dan pemudi sulit diajak bergabung untuk mendukung keberadaan Desa wisata, namun kami sebagai pengurus tidak boleh patah semangat terus memberikan pemahaman kepada para pemuda dan pemudi, sampai saat ini baru ada 9 pemuda yang ikut aktif mengurus desa wisata dari sejumlah itu baru 3 pemuda yang minat sebagai pemasar. Dari ketiga pemuda hanya satu yang selalu menyertai Pak Sardi untuk ikut menjalankan pemasaran langsung, 2 pemuda lainnya baru sifatnya membantu dalam penyebaran leflet/brosur. Kami sudah bertekat untuk mengembangkan pemasaran melalui internet hanya saja tenaga kaum muda belum banyak yang menguasai, maka kami selaku pengurus minta bantuan keberbagai pihak untuk memberikan pelatihan IT (Ilmu Teknologi). Direncanakan bulan Maret 2017 kami akan diberikan pelatihan tenaga pemasaran termasuk bidang internet oleh Dinas Pariwisata Kaupaten Bantul”.

Dampak terhadap aspek Ekonomi, Sosial dan Budaya

Desa wisata Kebonagung menganut pola pengembangan pariwisata berkelanjutan atau community based tourism (CBT), sehingga memberikan keluasan kepada masyarakat sebagai pelaku utama kegiatan pariwisata di Desa Wisata Kebonagung.. Dampak terhadap aspek ekonomi tercermin pada partisipasi masyarakat dalam sektor usaha atau pekerjaan masyarakat yang menunjukkan perkembangan

\begin{tabular}{|c|l|c|}
\hline No & \multicolumn{1}{|c|}{ Jenis Pekerjaan } & Jumlah Pekerja \\
\hline 1 & Pekerjaan sebagai Pokdarwis Desa Wisata & 19 \\
2 & Pekerjaan sebagai petugas parkir & 2 \\
3 & Pekerjaan sebagai pemandu wisata & 7 \\
4 & Pekerjaan sebagai petugas keamanan & 4 \\
5 & Pekerjaan sebagai pelaku kesenian & 23 \\
6 & Pekerja kulinary & 5 \\
7 & Pekerjaan sebagai petugas kebersihan & 8 \\
\hline
\end{tabular}

Selain mendapatkan pekerjaan baru, ada beberapa masyarakat yang memiliki usaha baru. Seperti yang dikatakan oleh Ibu Asih berdasarkan hasil wawancara yang dilakukan oleh penulis: "Saya senang. Adanya desa wisata ini memberikan banyak manfaat buat saya. Sekarang saya bisa memiliki tambahan penghasilan dari usaha baru saya. Berjualan pakaian, gorengan, dan minuman. Lumayan hasil berjualan bisa untuk ditabung dan cukup untuk memenuhi kebutuhan sehari-hari".

Samahalnya yang disampaikan ibu Sugiarti sebagai seksi kulinary mengatakan bahwa "keberadaan desa wisata ini memberikan kesibukan, memberikan penghasilan tapi 
juga memberikan ilmu untuk berusaha maupun ilmu masak jadi ya seneng adanya desa wisata ini karena para ibu-ibu jadi lebih terbuka wawasannya khususnya dalam hal masak memasak maupun wirausaha".

Sedangkan dampak pada aspek sosial budaya masyarakat tercermin dalam beberapa struktur populasi, transformasi mata pencaharian, pola struktur populasi, pola kehidupan sehari-hari dan dampak terhadap individu dan keluarga. Berdasarkan hasil observasi berbagai dampak tersebut tersaji dalam tabeltabel berikut :

Tabel 2. Pola Struktur Populasi

\begin{tabular}{|l|l|l|}
\hline Dampak Sosial & \multicolumn{1}{|c|}{ Deskripsi di Desa Wisata Kebonagung } & $\begin{array}{c}\text { Potensi } \\
\text { Dampak }\end{array}$ \\
\hline $\begin{array}{l}\text { Perubahan } \\
\text { struktur } \\
\text { populasi }\end{array}$ & $\begin{array}{l}\text { Tidak ada perubahan terhadap struktur populasi, sehingga masyarakat lokal dapat } \\
\text { memaksimalkan peluang kerja dan peluang usaha baru di Desa Wisata, namun hal } \\
\text { ini dipandang sebagai kendala untuk kemajuan karena desa wisata ini butuh } \\
\text { pengetahuan- pegetahuan khususnya dalam hal pemasaran }\end{array}$ & $\begin{array}{l}\text { Belum } \\
\text { Positif }\end{array}$ \\
\hline
\end{tabular}

Tabel 3. Transformasi Mata Pencaharian Masyarakat

\begin{tabular}{|c|c|c|c|}
\hline No & $\begin{array}{l}\text { Dampak sosial: } \\
\text { Perubahan struktur } \\
\text { mata pencaharian }\end{array}$ & Deskripsi di Desa Wisata Kebonagung & $\begin{array}{l}\text { Potensi } \\
\text { Dampak }\end{array}$ \\
\hline 1 & Kesempatan kerja & $\begin{array}{l}\text { Industri pariwisata di Desa Wisata Kebonagung mampu memberikan } \\
\text { kesempatan kerja baru bagi masyarakat lokal. Antusiasme masyarakat } \\
\text { lokal pun tinggi terhadap pariwisata sehingga banyak masyarakat yang } \\
\text { kini memiliki pekerjaan sampingan disektor pariwisata. Jenis pekerjaan } \\
\text { tersebutyaitu: } \\
\text { - Pokdarwis, terdapat } 19 \text { pendudukyang bekerja sebagai pokdarwis. } \\
\text { - Pemandu wisata, terdapat } 7 \text { penduduk yang bekerja sebagai } \\
\text { pemandu wisata. } \\
\text { - Petugas parkir, terdapat } 2 \text { penduduk yang bekerja sebagai petugas } \\
\text { parkir. } \\
\text { Petugas keamanan, terdapat } 4 \text { penduduk yang bekerja sebagai } \\
\text { petugas keamanan. } \\
\text { Petugas kebersihan, terdapat } 8 \text { penduduk yang bekerja sebagai } \\
\text { petugas kebersihan. } \\
\text { Pelaku seni, terdapat } 23 \text { penduduk yang bekerja sebagai pelaku } \\
\text { kesenian. } \\
\text { dan } 5 \text { orang sebagai tenaga kulinary }\end{array}$ & $\begin{array}{l}\text { Cukup } \\
\text { Positif }\end{array}$ \\
\hline 2 & Peluang usaha & $\begin{array}{l}\text { Industri pariwisata di Desa Wisata Kebonagung berdampak positif, yaitu } \\
\text { memunculkan peluang usaha baru kepada masyarakat lokal. Peluang } \\
\text { usaha tersebut yaitu: } \\
\text { - Usaha homestay, terdapat } 17 \text { penduduk yang mengembangkan } \\
\text { rumahnya menjadi usaha homestay untuk menunjang kebutuhan } \\
\text { akomodasi wisatawan. Usaha homestay memberikan tambahan } \\
\text { penghasilan yang cukup banyak kepadamasyarakat. } \\
\text { - Usaha cenderamata, terdapat } 1 \text { penduduk. }\end{array}$ & $\begin{array}{l}\text { Belum } \\
\text { Positif }\end{array}$ \\
\hline
\end{tabular}

Tabel 4. Transformasi Tata Nilai

\begin{tabular}{|c|c|c|c|}
\hline No & $\begin{array}{c}\text { Dampak sosial: } \\
\text { Perubahan tata } \\
\text { nilai }\end{array}$ & \multicolumn{1}{|c|}{ Deskripsi di Desa Wisata Kebonagung } & $\begin{array}{c}\text { Potensi } \\
\text { Dampak }\end{array}$ \\
\hline 1 & Peniruan & $\begin{array}{l}\text { Masuknya kebudayaan asing ke Desa Wisata Kebonagung hingga saat ini } \\
\text { tidak memberikan efek peniruan terhadap masyarakat lokal seperti cara } \\
\text { berpakaian atau gaya hidup. Masyarakat tetap hidup sederhana dan } \\
\text { masih tradisional. Namun, masyarakat mulai mengikuti dan belajar bahasa } \\
\text { asing yang dibawa wisatawan, seperti bahasa inggris maupun bahasa } \\
\text { daerah asal wisatawan. Meskipun belajar bahasa asing, masyarakat tetap } \\
\text { menggunakan bahasa daerahnya sendiri. }\end{array}$ & Positif \\
\hline 2 & Marginalisasi & $\begin{array}{l}\text { Hingga saat ini belum ada penduduk yang termarginalisasi atau } \\
\text { penduduk yang menolak asimilasi secara penuh kebudayaan yang dibawa } \\
\text { wisatawan ke dalam kehidupan sehari-hari. Semua masyarakat menerima } \\
\text { segala kegiatan pariwisata yang dilakukan di Desa Wisata Kebonagung. }\end{array}$ & Positif \\
\hline
\end{tabular}




\begin{tabular}{|c|c|c|c|}
\hline No & $\begin{array}{l}\text { Dampak sosial: } \\
\text { Perubahan tata } \\
\text { nilai }\end{array}$ & \multicolumn{1}{|c|}{ Deskripsi di Desa Wisata Kebonagung } & $\begin{array}{c}\text { Potensi } \\
\text { Dampak }\end{array}$ \\
\hline 3 & $\begin{array}{l}\text { Komodifikasi } \\
\text { Kebudayaan }\end{array}$ & $\begin{array}{l}\text { Sampai saat ini, tidak terjadi komodifikasi kebudayaan di Desa Wisata } \\
\text { Kebonagung. Kesenian dan kebudayaan seperti sholawatan hadroh } \\
\text { dilakukan sesuai dengan hukum adat yang berlaku di desa. Namun } \\
\text { kesenian seperti tari, jathilan, dan kubro siswo yang dikemas didalam } \\
\text { paket wisata dapat ditampilkan pada setiap saat. Selain memperkenalkan } \\
\text { kesenian yang dimilikinya, Desa Wisata Kebonagung juga ikut } \\
\text { melestarikan kesenian. }\end{array}$ & \\
\hline
\end{tabular}

Tabel 5. Dampak Terhadap Kehidupan Sehari-hari

\begin{tabular}{|c|c|c|c|}
\hline No & $\begin{array}{l}\text { Dampak terhadap } \\
\text { kehidupan sehari- } \\
\text { hari masyarakat }\end{array}$ & Deskripsi di Desa Wisata Kebonagung & $\begin{array}{l}\text { Potensi } \\
\text { Dampak }\end{array}$ \\
\hline 1 & $\begin{array}{l}\text { Terlalu sesaknya } \\
\text { orang }\end{array}$ & $\begin{array}{l}\text { Tidak terjadi. Sampai saat ini, jumlah kunjungan wisatawan belum pernah } \\
\text { menimbulkan sesaknya orang meskipun dalam jumlah banyak. Pengelola } \\
\text { selalu memperhatikan kapasitas yang dimiliki untuk menerima } \\
\text { wisatawan, sehingga antara wisatawan dan masyarakat dapat merasakan } \\
\text { kenyamanan dan tidak ada yang merasa dirugikan karena banyaknya } \\
\text { jumlah pengunjung. }\end{array}$ & Positif \\
\hline 2 & $\begin{array}{l}\text { Kemacetan } \\
\text { lalu lintas }\end{array}$ & $\begin{array}{l}\text { Tidak terjadi kemacetan lalu lintas di Desa Wisata Kebonagung. Hal ini } \\
\text { disebabkan karena adanya } 2 \text { jalur menuju destinasi, sehingga tidak } \\
\text { memungkinkan untuk terjadi kemacetan lalu lintas. }\end{array}$ & Positif \\
\hline 3 & $\begin{array}{l}\text { Adanya tindak } \\
\text { kejahatan yang } \\
\text { dilakukan wisatwan }\end{array}$ & $\begin{array}{l}\text { Tidak ada. Sampai saat ini, wisatawan yang datang selalu memiliki } \\
\text { perilaku yang baik. Sehingga tidak pernah merugikan masyarakat. Selain } \\
\text { itu, wisatawan juga tidak pernah membawa benda tajam atau berbahaya } \\
\text { maupun membawa obat-obatan terlarang selama berada di Desa Wisata } \\
\text { Kebonagung. }\end{array}$ & Positif \\
\hline 4 & $\begin{array}{l}\text { Adanya tindak } \\
\text { kejahatan kepada } \\
\text { wisatawan }\end{array}$ & $\begin{array}{l}\text { Tidak ada tindakan kejahatan kepada wisatawan yang dilakukan oleh } \\
\text { masyarakat lokal. Masyarakat justru membantu dalam menjaga keamanan } \\
\text { lingkungan Desa Wisata Kebonagung. }\end{array}$ & Positif \\
\hline 5 & $\begin{array}{l}\text { Penggunaan } \\
\text { infrastruktur yang } \\
\text { berlebihan }\end{array}$ & $\begin{array}{l}\text { Tidak terjadi. Infrastruktur di Desa Wisata Kebonagung sebagian besar } \\
\text { memanfaatkan milik desa, sehingga masyarakat dan wisatawan selalu } \\
\text { diberikan arahan untuk menggunakan dengan sewajarnya. }\end{array}$ & Positif \\
\hline 6 & $\begin{array}{l}\text { Kehilangan } \\
\text { manfaat dan } \\
\text { usaha lain }\end{array}$ & $\begin{array}{l}\text { Tidak terjadi. Industri pariwisata justru memberikan peluang bagi } \\
\text { masyarakat untuk memiliki usaha baru seperti usaha homestay, usaha } \\
\text { berjualan makanan dan minuman, cinderamata dan lain sebagainya. }\end{array}$ & Positif \\
\hline 7 & $\begin{array}{l}\text { Polusi desain } \\
\text { arsitektur }\end{array}$ & $\begin{array}{l}\text { Tidak terjadi. Hingga saat ini, Desa Wisata Kebonagung masih menjaga } \\
\text { keaslian wilayah desanya, agar wisatawan dapat meraskan suasana } \\
\text { pedesaan. Sehingga belum ada investor asing yang membangun hotel } \\
\text { maupun restoran besar. }\end{array}$ & Positif \\
\hline 8 & $\begin{array}{l}\text { Kehilangan } \\
\text { kegunaan dan } \\
\text { manfaat sosial } \\
\text { tanah }\end{array}$ & $\begin{array}{l}\text { Tidak terjadi. Pengembangan fasilitas wisata untuk wisatawan seperti } \\
\text { toilet umum juga dapat digunakan oleh masyarakat dan tidak } \\
\text { mengurangi manfaat sosial tanah. }\end{array}$ & Positif \\
\hline
\end{tabular}




\begin{tabular}{|c|c|c|c|}
\hline No & $\begin{array}{l}\text { Dampak terhadap } \\
\text { individu dan } \\
\text { keluarga }\end{array}$ & Deskripsi di Desa Wisata Kebonagung & $\begin{array}{l}\text { Potensi } \\
\text { Dampak }\end{array}$ \\
\hline 1 & $\begin{array}{l}\text { Meningkatkan } \\
\text { peluang berwisata }\end{array}$ & $\begin{array}{l}\text { Ya. Masyarakat kini memiliki peluang untuk berwisata. Masyarakat juga } \\
\text { ingin merasakan berwisata dengan keluarga di suatu destinasi wisata } \\
\text { yang berbeda dengan tempat tinggalnya untuk merasakan suasana dan } \\
\text { pengalaman baru. }\end{array}$ & Positif \\
\hline 2 & $\begin{array}{l}\text { Bertambahnya } \\
\text { interaksi sosial }\end{array}$ & $\begin{array}{l}\text { Ya. Seringnya bertemu dengan orang asing atau wisatawan meningkatkan } \\
\text { interaksi sosial antara masyarakat dengan wisatawan, selain itu interaksi } \\
\text { antar masyarakat juga semakin meningkat dengan adanya rapat } \\
\text { pertemuan desa. }\end{array}$ & \\
\hline 3 & $\begin{array}{l}\text { Meningkatkan } \\
\text { kualitas hidup }\end{array}$ & $\begin{array}{l}\text { Kualitas hidup masyarakat meningkat tetapi belum dikatakan berarti } \\
\text { karena keberadaan desa wisata ini belum sepenuhnya bisa diharapkah. } \\
\text { Hal ini ditandai dengan adanya kegiatan sehari-hari masyarakat yang lebih } \\
\text { bermanfaat karena adanya industri pariwisata. Seperti masyarakat dapat } \\
\text { berjualan, dapat bekerja sebagai pokdarwis, dan lain sebagainya. Selain } \\
\text { itu juga masyarakat memiliki tambahan pengetahuan karena adanya } \\
\text { interaksi dengan wisatawan. }\end{array}$ & \\
\hline 4 & $\begin{array}{l}\text { Meningkatkan } \\
\text { kemampuan } \\
\text { berbahasa }\end{array}$ & $\begin{array}{l}\text { Industri pariwisata di Desa Wisata Kebonagung belum dapat dirasakan } \\
\text { adanya meningkatnya kemampuan masyarakat baik dalam hal dunia } \\
\text { pariwisata maupun kemampuan berbahasa asing bagi masyarakat. }\end{array}$ & \\
\hline 5 & $\begin{array}{l}\text { Meningkatkan } \\
\text { kesantunan dan } \\
\text { tata krama }\end{array}$ & $\begin{array}{l}\text { Sebelum adanya industri pariwisata, masyarakat Desa Wisata } \\
\text { Kebonagung selalu menjaga kesantunan dan tata krama antar masyarakat. } \\
\text { Hingga saat ini, kesantunan dan tata krama semakin ditingkatkan oleh } \\
\text { setiap individu agar dapat memberikan keramahtaman yang baik dan } \\
\text { memberikan kenangan yang indah terhadap setiap wisatawan yang } \\
\text { berkunjung. }\end{array}$ & \\
\hline
\end{tabular}

\section{Konsep Rumusan Strategi Direkomendasikan}

Berdasarkan berbagai pertimbangan atas berbagai hasil temuan lapangan dapat dirumuskan strategi yang mendekati terhadap tujuan dan pengembangan pada Desa Wisata Kebonagung. Kalau selama ini lebih banyak mendekatkan pada strategi konflik dalam pemberdayaan terhadap masyarakat maka untuk selanjutnya perlu dimunculkan strategi dengan pendekatan baru yaitu strategi pendekatan yang berbasis gotong royong dan strategi pendekatan pembelotan kultural. Kalau pada awalnya Desa wisata ini hanya melibatkan atau memberdayakan pada kelompok-kelompok tertentu (strategi konflik) maka sedikit demi sedikit mulai berubah pada pemberdayaan masyarakat yang lebih luas.

Pendekatan pada pola gotong royong dimasyarakat pedesaan merupakan warisan para leluhur, hal ini didasarkan pada sikap dan budaya masyarakat berbasis pada pola paguyuban (kental dengan aspek kerukunan, tepo seliro saling membantu). Pola pendekatan ini lebih mengutamakan pada keterlibatan masyarakat dalam jumlah besar tanpa memperhatikan pada aspek kualitas. Namun demikian cara ini dipandang paling strategis dalam pemberdayaan masyarakat di pedesaan yang memiliki karakter komunikatif, keinginan untuk dihormati (diuwongke), jiwa sosial yang tinggi bekerja tanpa pamrih, kebersamaan, bergerombol.

Demikian pada strategi pembelotan kultural, masyarakat pedesaan yang berorientasi pada konsep memanusiakan manusia, saling menghormati harkat dan martabat sesama masyarakat, berkesan sebagai mitra kerja bukan sebagai buruh pabrik. Pola pengelolaan seperti ini sangat diharapkan dalam mengelola sebuah organisasi yang berbasis pada kepentingan masyarakat seperti halnya desa wisata.

Implementasi strategi ini mencakup bidang ekonomi, sosial maupun budaya. Masyarakat semakin hari semakin sadar bahwa setiap desa memiliki potensi untuk dijadikan komoditas wisata unggulan. Keindahan dan keunikan alam akan menjadi wisata alam. Jika desa tersebut memiliki keunikan tradisi dan budayanya bisa menjadi destinasi wisata budaya. Jika desa tersebut memiliki menu makanan dan minuman khas tradisional yang unik baik dari bahan, rasa dan penyajiannya, bisa dijadikan destinasi wisata kuliner desa. Jika desa tersebut memiliki kerajinan-kerajinan khas nan unik bisa menjadi destinasi wisata suvenir desa. Atau jika desa tersebut memiliki peninggalan-peninggalan yang mempunyai nilai sejarah yang tinggi atau situs sejarah/prasejarah bisa menjadi tujuan wisata sejarah desa. Bahkan jika desa itu memiliki keunggulan hasil bumi atau hasil laut misalnya pertanian, perkebunan, perikanan dan lain-lain. Dunia wisata dalam kekinian banyak mengalami perkembangan yang cukup signifikan. Apapun bisa dijadikan wisata yang mendatangkan keuntungan ekonomi bagi warga sekitar, asal jeli melihat dan memanfaatkan peluang. 
Rekomendasi utama yang disampaikan dari hasil penelitian adalah memperkuat adanya stategi yang berbasis pada pola gotong royong pada masyarakat. Dalam strategi gotong royong, melihat masyarakat sebagai sistem sosial. Artinya masyarakat terdiri dari atas bagian-bagian yang saling kerjasama untuk mewujudkan tujuan bersama. Gotong royong dipercaya bahwa perubahan-perubahan masyarakat, dapat diwujudkan melalui partisipasi luas dari segenap komponen dalam masyarakat. Prosedur dalam gotong royong bersifat demokratis, dilakukan diatas kekuatan sendiri dan kesukarelaan.

Identifikasi potensi desa melalui rembug bersama seluruh komponen desa dari semua kalangan. Potensi yang bisa menjadi komoditas bisa bermacam-macam dari segala aspek. Bisa keindahan alam, hasil bumi, kekayaan flora fauna/hayati, sosio kultural, masyarakat, tradisi atau hal-hal yang bersifat khas/unik yang tak dimiliki daerah lain. Melalui strategi ini dirasa efektif untuk mengenali dan memastikan berbagai potensi unggulan yang akan dijadikan komoditas utama.

Strategi pembelotan kultural, menekankan pada perubahan tingkat subyektif individual, mulai dari perubahan nilai-nilai pribadi menuju gaya hidup baru yang manusiawi. Yaitu gaya hidup cinta kasih terhadap sesama dan partisipasi penuh komunitas orang lain. Dalam bahasa Pancasila adalah humanis-relegius. Strategi ini merupakan reaksi (pembelotan) terhadap kehidupan masyarakat modern industrial yang berkembang berlawanan dengan pengembangan potensi kemanusiaan.

Dalam strategi ini harkat dan martabat manusia untuk sepenuhnya diakui, komunikasi sosial bersifat sebagai mitra bukan sebagai komunikasi buruh dan majikan. Konsep seperti ini dikenal dengan pola pariwisata yang berbasis pada masyarakat CBT (Community Base Tourism). Menurut Muallisin (2007 :7) CBT adalah pariwisata yang menyadari kelangsungan budaya, sosial dan lingkungan. Bentuk pariwisata ini dikelola dan dimiliki oleh masyarakat guna membantu para wisatawan untuk meningkatkan kesadaran mereka dan belajar tentang masyarakat dan tata cara hidup masyarakat lokal (local way of life). Sedangkan menurut Bambang Sunaryo (213:129); pembangunan pariwisata yang berbasis masyarakat merupakan proses perubahan pokok yang dilakukan manusia terencana dari kondisi kurang baik diarahkan menuju yang lebih baik.

Awal sejarah berdirinya desa wisata Kebonangung berbasis pada keinginan dan niat masyarakat hal ini menunjukkan bahwa pemberdayaan masyarakat secara murni sudah ada sejak dulu. Pada dasarnya desa wisata ini terbentuk, tumbuh dan berkembang didasarkan pada basis pemberdayaan masyarakat.

Hal lain yang bisa ditunjukkan bahwa program pemberdayaan ini sudah ada dan berkembang di desa wisata ini adalah semua aktivitas masyarakat merupakan suatu rangkaian kegiatan yang dapat sebagai produk wisata, seperti halnya keaslian pedesaan, budaya adat istiadat keseharian warga desa, bangunan, atraksi kesenian, kuliner dan lain-lain. Keaktifan dan partisipasi masyarakat sebagai pelaku kegiatan masyarakat juga ditunjukkan bahwa sebagian besar masyarakat menyediakan kamar rumahnya untuk kepentingan wisatawan sebagai penginapan/homestay.

Kuatnya tingkat komonitas masyarakat terhadap keberadaan desa wisata akan memberikan berbagai inspirasi rasa handarbeni (self of belonging) dengan timbulnya rasa ingin belajar terhadap manajemen kepariwisataan maupun penguatan pada keinginan untuk belajar pada hal-hal yang sukses.

Berkaitan dengan persoalan pemasaran berdasarkan hasil penelitian ditemukan bahwa rendahnya tingkat promosi atau kegiatan pemasaran yang masih konvesional artinya hanya mengandalkan beberapa orang yang memiliki relasi dengan orang lain. Hal ini tentunya sudah tidak lagi untuk dipertahankan melainkan untuk segera diganti dengan model pemasaran yang lebih canggih dengan memanfaatkan sosial media maupun melalui pendekatan yang berbasis pada teknologi dan jaringan yang lebih luas.

\section{KESIMPULAN DAN REKOMENDASI}

Berdasarkan hasil temuan lapangan dan pembahasan yang telah dilakukan pada bab terdahulu dapat diambil beberapa kesimpulan dan rekomendasi penelitian sebagai berikut

Kesimpulan

1. Desa wisata Kebonagung memiliki potensi alam dan buatan sebagai daya tarik tetapi masih perlu adanya pengelolaan lebih lanjut agar dapat bersaing dengan desa-desa wisata lain dalam upaya meningkatkan jumlah kunjungan.

2. Keterbatasan tenaga, pengetahuan yang selama ini dimiliki oleh para pengelola masih terbatas khususnya tenaga pemasaran dan pengetahuan tentang Teknologi Informasi (TI), hal ini berakibat pada rendahnya jumlah kunjungan khususnya kunjungan wisatawan mancanegara. Faktor aksesibilitas informasi tentang desa wisata benarbenar belum tersentuh sehingga desa wisata ini nyaris tidak dikenal oleh wisatawan.

3. Desa wisata Kebonangung telah mampu memberdayakan masyarakat tetapi masih belum seperti yang diharapkan, oleh sebab itu butuh motivator dan inspirator untuk secara persuasif mengajak para kaum muda, kelompok masyarakat yang ada di kawasan wilayah desa Kebonangung, sehingga konsentrasi pada pemberdayaan masyarakat bisa maksimal.

4. Upaya pengembangan desa wisata Kebonagung sebagai desa wisata unggulan di Kecamatan Imogiri Kabupaten Bantul perlu adanya berbagai perubahan dan penambahan strategi untuk dapat berkembang dalam memberdayakan masyarakat. Seperti yang terjadi saat ini pola strategi yang diterapkan belum sepenuhnya bisa dijalankan terbukti dari berbagai hasil wawancara bahwa masih cukup banyak masayarakat dan kelompok masyarakat yang belum berpartisipasi keberadaan desa wisata. 
5. Pengelola desa wisata menyadari kurangnya pengetahuan para pengurus dalam hal menjalin kerjasama oleh sebab itu pengurus sangat berharap adanya berbagai bimbingan pihak luar baik pemerintah maupun swasta agar dapat meningkatkan pengetahuan dan menarik partisipasi masyarakat lain untuk sepenuhnya mendukung keberadaan desa wisata tersebut.

\section{Rekomendasi}

1. Pola pengembangan strategi pemberdayaan masyarakat dikuatkan melalui strategi yang berbasis pada strategi gotong royong tidak lagi pada strategi konflik. Hal ini penting mengingat masyarakat desa Kebonagung masih kental dengan budaya paguyuban, kebersamaan, komunikatif dan toleransi yang tinggi terhadap berbagai resiko sosial yang dihadapi. Pola strategi ini dapat dipakai untuk membalikkan strategi konflik yang selama ini dijalankan, dimana dalam strategi konflik partisipasi masyarakat sangat terbatas sehingga ada sebagian masyarakat yang merasa tersingkirkan.

2. Pola pengembangan strategi kedua yang perlu direkomendasikan adalah pola strategi pembelotan kultural. Dalam strategi ini diharapkan dapat meningkatkan angka partisipasi masyarakat karena dalam strategi ini tidak memandang derajat pangkat pada setiap anggota dan pengurus, tetapi pola persuasif untuk mengajak masyarakat untuk bersama-sama memiliki dan bertanggung jawab (self of belonging). Tidak ada kesan hubungan buruh dan majikan tetapi kebersamaan dalam satu tujuan, baik dalam hal berpendapat maupun dalam hal pembagian kesejahteraan.

3. Pola pengembangan strategi manajemen, dalam hal ini adalah pengembangan pengelolaan desa wisata. Sasaran dari strategi ini adalah peningkatan menejemen melalui studi banding, maupun peningkatan kerjasama baik secara vertikal maupun horizontal. Hal ini dimaksudkan untuk memperluas pengetahuan manajemen maupun memperluas jaringan pemasaran sehingga potensi desa wisata yang ada selama ini dapat ditingkatkan dan dapat dikenal oleh wisatawan. Perluasan jaringan atau perluasan aksesibilitas ini akan mempermudah mendapatkan perhatian pada pihak luar baik swasta maupun pemerintah.

\section{REFERENSI}

Anonim Proyek Pemanfaatan Kebudayaan Daerah DIY, 2003. Petunjuk Teknis Penelitian Budaya, Yogyakarta : P2KD Diy 2003.

Bambang S. Kebijakan pembangunan Destinasi Konsepdan aplikasinya di Indonesia. Yogyakarta: 2013 Gava media

I Gede Pitana Keynote Speaker dalam seminar nasional Pariwisata dan air, Jakarta 4 Oktober 2013)

Indriantoro, Nur dan Bamabang Supomo. Metodologi Penelitian Bisnis. 2002. BPFE-Yogyakarta.

J, Nasikun Mencari Suatu Strategi Pembangunan Masyarakat Desa Berparadigma Ganda, dalam Jefta Leibo, Sosiologi Pedesaan, : 1995 Andi Offset, Yogyakarta.

Robert J. Kodoatic, Dkk, , "Pengelolaan SDA dalam Otonomi Daerah”:2004 Penerbit Andi, Yogyakarta.

Muallisin : Model Pengembangan Pariwisata Berbasis Masyaakat di Kota Yogyakarta 2007 jurnal Penelitian BAPEDA Yogyakarta Vol 2. No. 1 (http://eprints.uns.ac.id/15139/1/Publikasi_jurnal_ (36) diakses pada hari Selasa, 28 Maret,2017)

RS Damardjati , 2001, Istilah-istilah Dunia Pariwisata , Pradnya Paramita, Jakarta

Sutoro, Eko, “Pemberdayaan Kaum Marginal”:2004 :APMD Press, Yogyakarta.

"Reformasi Politik dan Pemberdayaan Masyarakat” :2004 : APMD Press, Yogyakarta.

. Pemberdayaan Masyarakat Desa, Materi Diklat Pemberdayaan Masyarakat Desa, yang diselenggarakan Badan Diklat Provinsi Kaltim, Samarinda, Desember 2002.

Sugiyono. Metode Penelitian Kuantitatif, Kualitatif, Dan R\&D.: 2011 : .Bandung: Alfabeta

Tazbir Abdullah Menjalin hubungan baik dengan masyarakat desa wisata, YOGYAKARTA, : KOMPAS.com Selasa (10/9/2013) 